\title{
Can Human Maxillary Premolars Discriminate Between Sexes in South Asian Populations?
}

\author{
¿Pueden los Premolares Maxilares Humanos Discriminar \\ entre Sexos en las Poblaciones del Sur de Asia?
}

Zeeshan Qamar ${ }^{1,2}$; Fayez Hussain Niazi ${ }^{2,3}$; Ahmed Abdul Moiz ${ }^{3}$; Mohammed Noushad ${ }^{3}$ \& Tayyaba Zeeshan ${ }^{4}$

QAMAR, Z.; NIAZI, F. H.; MOIZ, A. A.; NOUSHAD, M. \& ZEESHAN, T. Can human maxillary premolars discriminate between sexes in South Asian Populations? Int. J. Morphol., 38(3):622-626, 2020.

SUMMARY: The studies have illustrated odontometric analysis can be used to determine the sexual dimorphism effect on size of the teeth in various populations. The main aim of the study was to identify the inter-cuspal-, bucco-lingual -dimensions and weight of human upper-arch pre-molars in males and females of different South Asian populations. These metrics can distinguish sex which can have application in mass disasters, archaeology of mingled human remains and the in unidentified or several ancestry. The sample size consisted of 60 orthodontically extracted maxillary pre-molars from Pakistani and Saudi Arabian populations respectively. For male and female groups of each population fifteen first and second maxillary premolars were collected respectively, stored in PBS solution. The weight of the individual teeth was recorded. Later, digitally pictures were captured parallel to the occlusal surface to measure maximal bucco-lingual and inter-cuspal dimensions using Image-J software. The dimensions and weights were compared using Students' t-test between males and females respective Pakistani and Saudi Arabian first (P1) and second (P2) maxillary pre-molars. The dimensions for male P1 and P2 were statistically significantly larger than that for females in both populations. Furthermore, wet-weight of pre-molars in males is significantly greater than females in both populations. The findings demonstrate maxillary pre-molars can discriminate between the sexes in various populations.

KEY WORDS: Morphology; Premolar; Sex; Discrimination.

\section{INTRODUCTION}

The sex identification in forensic medicine is usually estimated from the bones of pelvis and skull (Meindl et al., 1985). But in forensic dentistry it appears to be challenging from respective teeth or jaw section. Though some evidences in forensic dentistry exist for sex determination by assessing the measurable and non-measurable dental features, pattern for development and eruption of tooth, presence of enamel protein amelogenin as well as DNA analysis of dental tissues (Vodanovic et al., 2007; Capitaneanu et al., 2017a). The precise technique suggested in forensic dentistry for sexing is the bio-chemical analysis of the teeth but due to certain limitations of availability and cost it is least practiced technique (Capitaneanu et al., 2017b). A group of researchers reported mesio-distal and bucco-lingual dimensions of crown or root length can be used for sex determination in Greeks adult population (Zorba et al., 2014). Similarly Iscan and co-workers (2003) displayed bucco-lingual dimension in
Turkish population for both maxillary and mandibular teeth is sex dependent, greater for males than females with accuracy 73-77\%. Narang et al. (2015) compared the bucco-lingual dimensions of first maxillary molar in North-Indian population, reported greater dimensions in males than females. This sexual dimorphism in tooth dimensions are thought to be related with thickness of dental hard tissues in particular enamel and dentin (Stroud et al., 1994; Macha et al., 2010). Later, Townsend (1985) determined the intercuspal dimension of maxillary pre-molars in Australian Aborigines and reported greater bucco-lingual dimension for males than the females. The aim of the study was to determine the weight, inter-cuspal- and bucco-lingual -dimension in Pakistani and Saudi Arabian population maxillary pre-molars for males and females. This ratio could be useful for analysis of individuals in case of natural disasters such as earthquakes when the sex identification is not possible.

\footnotetext{
${ }^{1}$ Department of OMFS and Diagnostic Sciences, Riyadh Elm University, Riyadh, Saudi Arabia.

${ }^{2}$ Department of Oral Biology, Liaquat College of Medicine and Dentistry, Karachi.

${ }^{3}$ Department of Restorative and Prosthetic Dentistry,Dar Al Uloom University, Riyadh, Saudi Arabia.

${ }^{4}$ Department of Oral \& Craniofacial Sciences, University Malaya, Malaysia.
} 


\section{MATERIAL AND METHOD}

Phosphate Buffer Saline (PBS) Solution. PBS solution prepared according to the manufacturer's instructions (Oxoid, U.K), $\mathrm{pH}$ adjusted to 7.0 by addition of $1 \mathrm{M} \mathrm{NaOH}$ was stored at room temperature until further use.

Extracted teeth. In this study after procurement of ethical approval from Ethical Committee of Faculty of Dentistry, Riyadh Elm University, Riyadh, Saudi Arabia sixty extracted sound orthodontically extracted maxillary pre-molars for both Pakistani and Saudi Arabian population respectively were included. After written consent from the patients, the teeth were obtained at the Maxillofacial Surgery Departments of Liaquat College of Medicine and Dentistry, Karachi, Pakistan and Riyadh Elm University, Riyadh Saudi Arabia.

The exclusion criteria's for section of teeth in this study were i) coronal caries and / or ii) with root caries / or iii) attrition / or iv) erosion / or v) restorations. The inclusion criterion for tooth selection was i) teeth with complete root formation, ii) orthodontically extracted and/ or iii) sound teeth. The teeth collected were stored in containers separately marked with patients' sex and containing phosphate buffer saline (PBS) solution until further use.

The weight of individual pre-molars was recorded in a mean of three for P1 and P2 of Pakistani and Saudi Arabian population.

Later, the apex of pre-molars was embedded in the acrylic resin to develop fixed reference point for photography. The occlusal surface of the maxillary premolars was photographed at right-angles to the central developmental groove and the mesial and distal pits of the crowns. The camera was fixed on photography tripod to standardize the distance between the teeth and camera. The occlusal surface of each pre-molar was captured twice and the best images were selected for evaluation purpose.
The most important features for selection of images from the occlusal aspect were that the total circumference and cuspal tips of both cusps should be clearly visible. Later the images were processed through Image-J software, USA for identification of cuspal tips and maximal bucco-lingual surface. For analysis, two measurements of all the pre-molars were selected i) maximal bucco-lingual dimension and ii) maximum inter-cuspal space as shown in Figure 1. These two dimensions were compared between both of the sexes using Student's t-test. For statistical analysis SPSS Software version 21 was used.

\section{RESULTS}

The wet -weight of the males were observed to be more than the females in Pakistani and Saudi Arabian populations respectively $(r \leq 0.05)$.

The inter-cuspal space in the P1 (first pre-molar) was observed to be larger in males $6.08 \pm 0.05$ for Pakistani and Saudi Arabian population as compared to females $6.0 \pm 0.04$ and 5.98 \pm 0.06 . Similarly for P2 in males $6.09 \pm 0.06$ and $6.08 \pm 0.05$ for both populations was statistically greater than those for females respectively $(r \leq 0.05)$ (Table I).

Furthermore, the distance between the bucco-lingual surfaces was larger for male groups than that for the female groups with statistically significant values $(r \leq 0.05)$ for both populations. On inter-population analysis for sexes respectively in relation to inter-cuspal and inter-surface dimensions, the values were observed to be statistically insignificant (Table I) $(r>0.05)$.

A-B different capital letters mean statistically significant inter-cuspal distance between Pakistani males and females first maxillary pre-molars (P1) $(r \leq 0.05)$; C-D different capital letters mean statistically significant intercuspal distance between Saudi Arabian males and females P1 $(r \leq 0.05)$; $a-b$ different lower case letters means
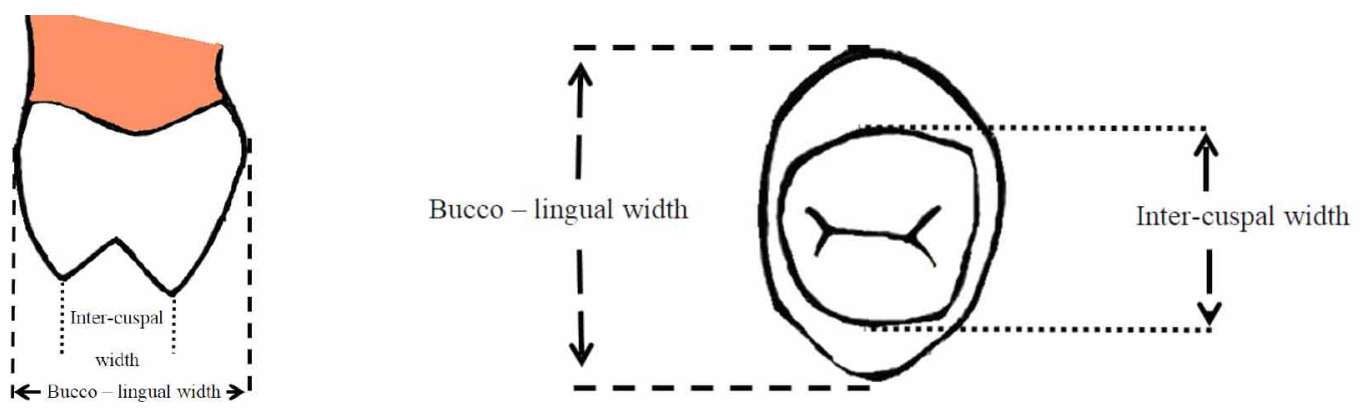

Fig. 1 Schematic maximal dimensions of bucco-lingual and inter-cuspal width for maxillary pre-molars. 
QAMAR, Z.; NIAZI, F. H.; MOIZ, A. A.; NOUSHAD, M. \& ZEESHAN, T. Can human maxillary premolars discriminate between sexes in South Asian Populations? Int. J. Morphol., 38(3):622-626, 2020.

Table I. Ratio of cups tip to maximum BL surface-, inter-cuspal - distance and weight of permanent maxillary first (P1) and second (P2) pre-molars in Pakistani and Saudi Arabian populations.

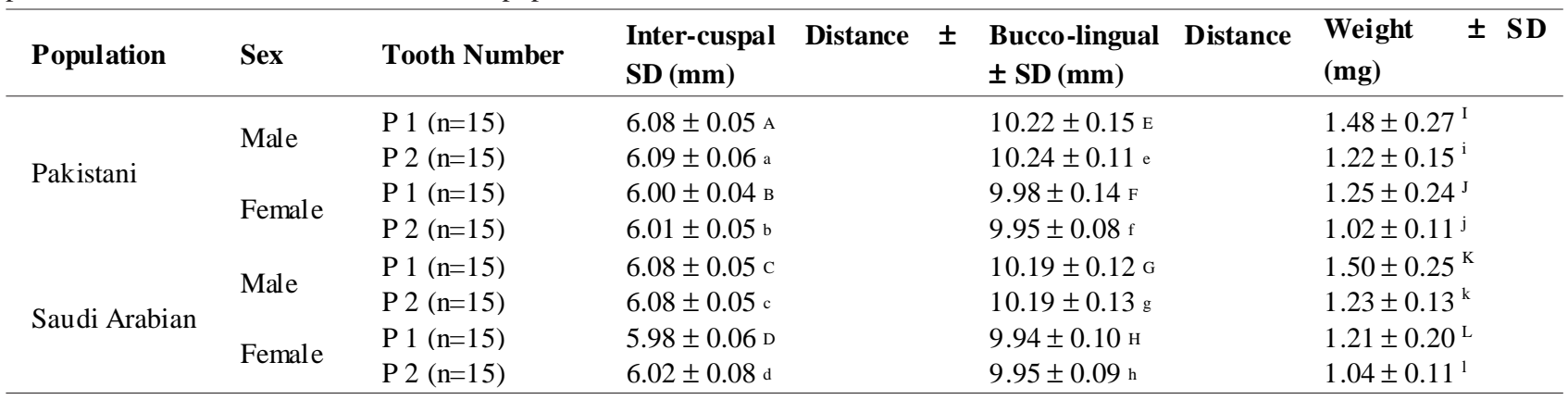

statistically significant inter-cuspal distance between Pakistani males and females second maxillary pre-molars (P2) $(r \leq 0.05)$; c-d different lower case letters means statistically significant inter-cuspal distance between Saudi Arabian males and females P2 ( $\mathrm{r} \leq 0.05)$; E-F different capital letters mean statistically significant bucco-lingual distance between Pakistani males and females P1 $(r \leq 0.05)$; G-H different capital letters mean statistically significant buccolingual distance between Saudi Arabian males and females P1 ( $r \leq 0.05)$; e-f different lower case letters mean statistically significant bucco-lingual distance between Pakistani males and females P2 $(r \leq 0.05)$; g-h different lower case letters mean statistically significant bucco-lingual distance between Saudi Arabian males and females P2 ( $\mathrm{r} \leq 0.05)$; I-J different capital letters mean statistically significant weight difference between Pakistani males and females P1 ( $\mathrm{r} \leq 0.05)$; K-L different capital letters mean statistically significant weight difference between Saudi Arabian males and females P1 $(r \leq 0.05)$; $i-j$ different lower case letters mean statistically significant weight difference between Pakistani males and females P2 ( $\mathrm{r} \leq 0.05)$; k-1 different lower case letters mean statistically significant weight difference between Saudi Arabian males and females P2 $(r \leq 0.05)$.

\section{DISCUSSION}

Odontological sexual dimorphism was observed to be greatest during stone-age referring to Paleolithic era than the current populations, which is in particular related to the bone mass reduction in relation to the evolution process (Pereira et al., 2010).

In recent days, researchers have reported dimensions of permanent dentition are greater in male than their sex counterpart (Adeyemi \& Isiekwe, 2003; Iscan \& Kedici, 2003; Rai \& Kaur, 2013; Sabóia et al., 2013), though this difference is least evident in deciduous dentition (Black,
1978). The permanent teeth observed to be most discriminative among the sexes are the canines (Pereira et al.; Capitaneanu et al., 2017a,b), probably related to evolution remainders of aggressive attitudes in males. The canines are followed by the first and second permanent molars for sex discrimination (Angadi et al., 2013; Tuttösí \& Cardoso, 2015; El Sheikhi \& Bugaighis, 2016).

Dimensional dimorphism of teeth could be related to the variable thickness of enamel and/or dentinal thickness as evident on genetic evaluation (Kieser \& Julius, 1990). The X-chromosome regulated the enamel thickness whereas Y-chromosome controls the dentinal thickness (Muller et al., 2001). In addition to that, researchers observed difference in the odontoblastic activity between two sexes. Zilberman et al. (2001) observed the dentinal thickness on the roof of the pulpal chambers was significantly greater in males than females during puberty.

Harris \& Hicks (1998) on radiographic examination of incisors demonstrated sex variations, males having greater mesio-distal dimensions in comparison to female group dependent on the dentinal thickness. They suggested the increase in mesio-distal width was dependent on the dentinal thickness (1998).

Numbers of studies reporting use of dental enamel for odontological sexing are negligible. Though studies have suggested possible reason for thin dental enamel is linked with gene ENAM which in-turn regulates secretion of enamel protein 'enamelin' (Daubert et al., 2016).

The parameters used in forensic dentistry for sex identification are considered as simple, reliable and inexpensive (Narang et al.). Though the parameters for sex evaluation vary between populations (Harris \& Hicks; Pereira et al.). Therefore it is important to define odontometric values for individual population which can help to distinguish sexes of respective population (Vodanovic et al.). 
It is a useful and inexpensive technique but certain limitations exist in odonto-metrics. Among them the most important limitation is sex identification for the individuals of unknown origin. In addition, an alteration in the normal dimensions of teeth due to attrition or abrasion of incisal and/or occlusal and/or proximal surfaces creates difficulty in sexing (Vodanovic et al.).

Further interestingly, researchers identified wet tooth weight as a tool for sex determination in forensic odontology. They reported heavier canines and 3rd molars than those of female group in the population (Schwartz \& Dean, 2005).

The results in our study displayed inter-cuspal-, bucco-lingual surface -dimensions and wet weight of premolars for both Pakistani and Saudi Arabian population can be used to identify the sexes as have statistically significant differences $(r \leq 0.05)$. But on comparing the inter-cuspal and bucco-lingual dimensions between two populations' respective sexes the difference observed was negligible.

\section{CONCLUSION}

The maximal bucco-lingual and inter-cuspal dimesions for maxillary pre-molars could not discriminate between the sexes for both Pakistani and Saudi Arabian population. But the pre-molar weight appeared to be an inappropriate tool for sex identification for both populations'.

QAMAR, Z.; NIAZI, F. H.; MOIZ, A. A.; NOUSHAD, M. \& ZEESHAN, T. ¿Pueden los premolares maxilares humanos discriminar entre sexos en las poblaciones del sur de Asia?. Int. J. Morphol., 38(3):622-626, 2020.

RESUMEN: Las investigaciones han ilustrado que el análisis odontométrico se puede utilizar para determinar el efecto del dimorfismo sexual en el tamaño de los dientes en varias poblaciones. El objetivo principal del estudio fue identificar las dimensiones y el peso entre cúspides, buco-linguales y el peso de los premolares de la arcada superior humana en hombres y mujeres de diferentes poblaciones del sur de Asia. Estas medidas pueden distinguir el sexo y ser importante en desastres masivos, arqueología de restos humanos entremezclados y en ancestros no identificados. El tamaño de la muestra consistió en 60 premolares maxilares extraídos ortodóncicamente de las poblaciones de Pakistán y Arabia Saudita, respectivamente. Para los grupos de hombres y mujeres de cada población, se recogieron quince primeros y segundos premolares superiores respectivamente, almacenados en solución de PBS. Se registró el peso de los dientes individuales. Posteriormente se capturaron imágenes digitales paralelas a la superficie oclusal para medir las dimensiones máximas buco-linguales e intercúspides utilizando software Image-J. Las dimensiones y los pe- sos se compararon mediante la prueba t de Student entre lo premolares maxilares (P1) y segundos (P2) de hombres y mujeres paquistaníes y saudíes. Las dimensiones para P1 y P2 de los hombres fueron estadísticamente significativos mayores que para las mujeres en ambas poblaciones. Además, el peso húmedo de los premolares en los varones era significativamente mayor que el de las mujeres en ambas poblaciones. Los hallazgos demuestran que los premolares maxilares pueden discriminar entre los sexos en varias poblaciones.

PALABRAS CLAVE: Morfología; Premolar; Sexo; Discriminación.

\section{REFERENCES}

Adeyemi, T. A. \& Isiekwe, M. C. Comparing permanent tooth sizes (mesiodistal) of males and females in a Nigerian population. West Afr. J. Med., 22(3):219-21, 2003.

Angadi, P. V.; Hemani, S.; Prabhu, S. \& Acharya, A. B. Analyses of odontometric sexual dimorphism and sex assessment accuracy on a large sample. J. Forensic Leg. Med., 20(6):673-7, 2013.

Black, T. K. 3rd. Sexual dimorphism in the tooth-crown diameters of the deciduous teeth. Am. J. Phys. Anthropol., 48(1):77-82, 1978.

Capitaneanu, C.; Willems, G. \& Thevissen, P. A systematic review of odontological sex estimation methods. J. Forensic Odontostomatol., 35(2):1-19, 2017b.

Capitaneanu, C.; Willems, G.; Jacobs, R.; Fieuws, S. \& Thevissen, P. Sex estimation based on tooth measurements using panoramic radiographs. Int. J. Legal Med., 131(3):813-21, 2017a.

Daubert, D. M.; Kelley, J. L.; Udod, Y. G.; Habor, C.; Kleist, C. G.; Furman, I. K.; Tikonov, I. N.; Swanson, W. J. \& Roberts, F. A. Human enamel thickness and ENAM polymorphism. Int. J. Oral Sci., 8(2):93-7, 2016.

El Sheikhi, F. \& Bugaighis, I. Sex discrimination by odontometrics in Libyan subjects. Egypt. J. Forensic Sci., 6(2):157-64, 2016.

Harris, E. F. \& Hicks, J. D. A radiographic assessment of enamel thickness in human maxillary incisors. Arch. Oral Biol., 43(10):825-31, 1998.

Iscan, M. Y. \& Kedici, P. S. Sexual variation in bucco-lingual dimensions in Turkish dentition. Forensic Sci. Int., 137(3-2):160-4, 2003.

Kieser, J. A. \& Julius, K. Human Adult Odontometrics: The Study of Variation in Adult Tooth Size. Cambridge, Cambridge University Press, 1990

Macha, A. de C.; Vellini-Ferreira, F.; Scavone-Junior, H. \& Ferreira, R. I. Mesiodistal width and proximal enamel thickness of maxillary first bicuspids. Braz. Oral Res., 24(1):58-63, 2010.

Meindl, R. S.; Lovejoy, C. O.; Mensforth, R. P. \& Don Carlos, L. Accuracy and direction of error in the sexing of the skeleton: implications for paleodemography. Am. J. Phys. Anthropol., 68(1):7985, 1985.

Muller, M.; Lupi-Pegurier, L.; Quatrehomme, G. \& Bolla, M. Odontometrical method useful in determining gender and dental alignment. Forensic Sci. Int., 121(3):194-7, 2001.

Narang, R. S.; Manchanda, A. S. \& Singh, B. Sex assessment by molar odontometrics in North Indian population. J. Forensic Dent. Sci., 7(1):54-8, 2015.

Pereira, C.; Bernardo, M.; Pestana, D.; Santos, J. C. \& Mendonça, M. C. Contribution of teeth in human forensic identification--discriminant function sexing odontometrical techniques in Portuguese population. J. Forensic Leg. Med., 17(2):105-10, 2010.

Rai, B. \& Kaur, J. Evidence-Based Forensic Dentistry. Berlin, Springer, 2013. 
Sabóia, T. M.; Tannure, P. N.; Luiz, R. R.; de Castro Costa, M.; Granjeiro, J. M.; Küchler, E. C. \& Antunes, L. S. Sexual dimorphism involved in the mesiodistal and buccolingual dimensions of permanent teeth. Dentistry 3000, 1(1):2-6, 2013.

Schwartz, G. T. \& Dean, M. C. Sexual dimorphism in modern human permanent teeth. Am. J. Phys. Anthropol., 128(2):312-7, 2005.

Stroud, J. L.; Buschang, P. H. \& Goaz, P. W. Sexual dimorphism in mesiodistal dentin and enamel thickness. Dentomaxillofac. Radiol., 23(3):169-71, 1994

Townsend, G. C. Intercuspal distances of maxillary pre-molar teeth in Australian aboriginals. J. Dent. Res., 64(3):443-6, 1985.

Tuttösí, P. \& Cardoso, H. F. V. An assessment of sexual dimorphism and sex estimation using cervical dental measurements in a Northwest Coast archeological sample. J. Archaeol. Sci. Rep., 3:306-12, 2015.

Vodanovic, M.; Demo, Z.; Njemirovskij, V.; Keros, J. \& Brkic', H. Odontometrics: a useful method for sex determination in an archaeological skeletal population? J. Archaeol. Sci., 34(6):905-13, 2007.

Zilberman, U. \& Smith, P. Sex- and age-related differences in primary and secondary dentin formation. Adv. Dent. Res., 15:42-5, 2001.

Zorba, E.; Vanna, V. \& Moraitis, K. Sexual dimorphism of root length on a Greek population sample. Homo, 65(2):143-54, 2014.
Corresponding author:

Dr. Zeeshan Qamar

B.D.S, M.Sc, PhD

Assistant Professor

Department of OMFS and Diagnostic Sciences

Riyadh Elm University

Riyadh

SAUDI ARABIA

Email: zeeshan.qamar@ymail.com

Received: 16-10-2019

Accepted: 04-11-2019 